\title{
Cupriavidus pinatubonensis sp. nov. and
Cupriavidus laharis sp. nov., novel hydrogen-
oxidizing, facultatively chemolithotrophic bacteria
isolated from volcanic mudflow deposits from Mt.
Pinatubo in the Philippines \\ Correspondence \\ Hiroyuki Ohta \\ hohta@mx.ibaraki.ac.jp \author{
Jose D. Rondal, ${ }^{3}$ Rogelio N. Concepcion ${ }^{3}$ and Hiroyuki Ohta ${ }^{1}$ \\ ${ }^{1}$ Department of Bioresource Science, Ibaraki University College of Agriculture, Ami-machi, \\ Ibaraki 300-0393, Japan \\ ${ }^{2}$ Department of Environmental Science and Technology, Interdisciplinary Graduate School of \\ Science and Engineering, Tokyo Institute of Technology, Nagatsuda, Midori-ku, Yokohama \\ 226-8503, Japan \\ ${ }^{3}$ Soils Research and Development Centre, Bureau of Soils and Water Management, Diliman, \\ Quezon City, Philippines
} \\ Yoshinori Sato, ${ }^{1}$ Hirofumi Nishihara, ${ }^{1}$ Masao Yoshida, ${ }^{1}$ Makiko Watanabe, ${ }^{2}$
}

\begin{abstract}
Taxonomic studies were performed on ten hydrogen-oxidizing, facultatively chemolithotrophic bacteria that were isolated from volcanic mudflow deposits derived from the eruption of Mt. Pinatubo in the Philippines in 1991. Phylogenetic analysis based on 16S rRNA gene sequences indicated that these isolates belonged to the genus Cupriavidus of the Betaproteobacteria; sequence similarity values with their nearest phylogenetic neighbour, Cupriavidus basilensis, were 97.1-98.3\%. In addition to phylogenetic analysis, results of whole-cell protein profiles and biochemical tests revealed that these strains were members of two distinct species. DNA-DNA hybridizations and whole-cell protein profiles enabled these isolates to be differentiated from related Cupriavidus species with validly published names. The isolates were aerobic, Gramnegative, non-sporulating, peritrichously flagellated rods. Their $\mathrm{G}+\mathrm{C}$ contents ranged from $65 \cdot 2$ to $65.9 \mathrm{~mol} \%$ and their major isoprenoid quinone was ubiquinone Q-8. On the basis of these results, two novel species are proposed, Cupriavidus pinatubonensis sp. nov. [nine strains, with $1245^{\top}$ $\left(=\mathrm{CIP} 108725^{\top}=\mathrm{PNCM} 10346^{\top}\right)$ as the type strain] and Cupriavidus laharis sp. nov. [one strain, the type strain $\left.1263 \mathrm{a}^{\top}\left(=\mathrm{CIP} 108726^{\top}=\mathrm{PNCM} 10347^{\top}\right)\right]$. It is also suggested that Ralstonia sp. LMG 1197 (= JMP 134) should be included in the species C. pinatubonensis.
\end{abstract}

One of the major subjects in terrestrial microbiology is to elucidate the role of microbes in the process of soil genesis and soil ecosystem development. New substrates derived from volcanic eruptions, e.g. lava, tephra and volcanic ash, contain negligible amounts of organic carbon and fixed nitrogen when first deposited (Chadwick et al., 1999). Consequently, rates of vegetation growth and other ecosystem processes are often constrained by the supply of nitrogen and carbon in early developing ecosystems on volcanic

The GenBank/EMBL/DDBJ accession numbers for the 16S rRNA gene sequences of strains $1243,1245^{\top}, 1246 \mathrm{a}, 1247,1250,1266$, $1278 \mathrm{a}, 1244 \mathrm{a}, 1249$ and $1263 \mathrm{a}^{\top}$ are $\mathrm{AB} 121220-\mathrm{AB} 121224$, AB121227, AB121228, AB054960, AB055427 and AB054961, respectively.

A figure showing whole-cell protein electrophoretic profiling of the group P strains is available as supplementary material in IJSEM Online. deposits. Under these conditions, carbon and energy sources for microbial community development derive from the colonization of phototrophs or lichens (Jackson \& Keller, 1970; Kurina \& Vitousek, 1999; Crews et al., 2001), dry and wet depositions of organic matter (King, 2003) and atmospheric inputs of trace gases (e.g. $\mathrm{CO}, \mathrm{H}_{2}$ and $\mathrm{CH}_{4}$ ) (Conrad, 1996). Recently, King (2003) showed that atmospheric $\mathrm{CO}$ and hydrogen utilization contribute $2-4 \%$ and 15-20\% of total respiratory reducing equivalent flow, respectively, in intact cores from recent Hawaiian volcanic deposits.

Previously, bacterial diversity of very recent volcanic deposits sampled from volcanic mudflow-affected areas around Mt. Pinatubo, the Philippines, has been analysed by quinone profiling (Ohta et al., 2003). Subsequently, pure bacterial cultures were isolated from such volcanic deposit 
samples and then subjected to comparative 16S rRNA gene sequence analysis. Analysis revealed that $25 \%$ of total culturable bacteria were phylogenetically related to a hydrogen-oxidizing bacterium, Ralstonia eutropha [recently transferred to the novel genus Wautersia (Vaneechoutte et al., 2004) and further reclassified as a synonym of Cupriavidus necator (Vandamme \& Coenye, 2004)], with similarities of $97 \cdot 3-98 \cdot 2 \%$ (Sato et al., 2004). Furthermore, most of the $C$. necator-related bacterial strains from the mudflow deposits grew chemolithoautotrophically with $\mathrm{H}_{2}$ as electron donor and $\mathrm{CO}_{2}$ as carbon source and also possessed hydrogenase activity (Sato et al., 2004). In the present study, the $C$. necator-related bacteria were further characterized and described using physiological characterization, DNADNA hybridization, determination of DNA base composition and whole-cell protein profiles. On the basis of these data, the two representative strains $\left(1245^{\mathrm{T}}\right.$ and $\left.1263 \mathrm{a}^{\mathrm{T}}\right)$ should be classified as the type strains of two novel species.

The ten strains under study $\left(1243,1244 \mathrm{a}, 1245^{\mathrm{T}}, 1246 \mathrm{a}\right.$, $1247,1249,1250,1263 \mathrm{a}^{\mathrm{T}}, 1266$ and $1278 \mathrm{a}$ ) were isolated in 1998 from the $0 \cdot 00-0 \cdot 25 \mathrm{~m}$ depth layer of the volcanic deposits at two sites [site $\mathrm{N}\left(15^{\circ} 15^{\prime} 17^{\prime \prime} \mathrm{N} 120^{\circ} 34^{\prime} 59^{\prime \prime} \mathrm{E}\right)$ and site $\mathrm{S} 1$ ( $2 \mathrm{~km}$ east of site $\mathrm{N})$ ] that had been hit repeatedly by mudflows during successive rainy seasons after the violent eruption of 1991 on the east side of Mt. Pinatubo (Ohta et al., 2003; Sato et al., 2004). C. necator JCM 11282 (the type strain of $W$. eutropha), Cupriavidus gilardii JCM $11283^{\mathrm{T}}$, Cupriavidus oxalaticus JCM $11285^{\mathrm{T}}$ and Cupriavidus pauculus JCM $11286^{\mathrm{T}}$ were obtained from the Japan Collection of Microorganisms, Wako-shi, Japan. Cupriavidus basilensis DSM $11853^{\mathrm{T}}$ was obtained from the DSMZ, Braunschweig, Germany, and Ralstonia sp. LMG 1197 (Pemberton et al., 1979), C. necator LMG 8453 ${ }^{\mathrm{T}}$, Cupriavidus campinensis LMG $19282^{\mathrm{T}}$, Cupriavidus metallidurans LMG $1195^{\mathrm{T}}$, Cupriavidus respiraculi LMG $21510^{\mathrm{T}}$ and Cupriavidus taiwanensis LMG $19424^{\mathrm{T}}$ were from BCCM/LMG Bacteria Collection, Laboratorium voor Microbiologie, Gent, Belgium. All strains were grown aerobically at $27^{\circ} \mathrm{C}$ on nutrient broth (NB) [1\% (w/v) Ehrlich meat extract (Kyokuto Seiyaku), 1\% (w/v) Trypticase peptone (Becton Dickinson) and $0.5 \%(\mathrm{w} / \mathrm{v}) \mathrm{NaCl}$, $\mathrm{pH} 7 \cdot 0$ with $1 \mathrm{M} \mathrm{NaOH}]$ or 100 -fold diluted $\mathrm{NB}\left(10^{-2} \mathrm{NB}\right)$, unless otherwise stated.

Classical phenotypic tests and analysis of isoprenoid quinones were performed as described by Ohta \& Hattori (1983). Growth of the strains at $41{ }^{\circ} \mathrm{C}$ on NB was monitored for 7 days. The API 20NE kit system (bioMérieux) was used according to the recommendations of the manufacturer. The substrate utilization profile was tested in a $10^{-2}$ NB liquid medium supplemented with each of the following compounds: sucrose, D-fructose, acetate, formate, glutamate, lactate, benzoate, caffeate, catechol, ferulate, guaiacol, phenol, vanillate, 2-hydroxybenzoate, 3,4-dihydroxybenzoate and 4-hydroxybenzoate. All compounds were sterilized by filtration and added to autoclaved $10^{-2} \mathrm{NB}$ medium. Sugars were added at a concentration of $0.2 \%(\mathrm{w} / \mathrm{v})$; organic acids and aromatic compounds were added at $0.02 \%(\mathrm{w} / \mathrm{v})$. Growth was measured after 2 days incubation and utilization was assessed by comparing growth in the presence and absence of an added compound. To compare cellular protein profiles, cells were grown for $48 \mathrm{~h}$ on NB at $27^{\circ} \mathrm{C}$. Whole-cell lysates were prepared essentially as described by Ohta et al. (1993) and onedimensional analytical SDS-PAGE was performed by the method of Laemmli (1970) with a $12.5 \%$ separating gel and $4.5 \%$ stacking gel. Proteins were visualized by silver staining with a commercial kit (Daiichi Pure Chemicals). The similarity between all pairs of electrophoresis patterns was calculated by the simple matching coefficient, expressed as a percentage. Cluster analysis was performed by the unweighted pair group method using arithmetic averages (UPGMA) clustering technique. The complete 16S rRNA gene sequences determined previously (Sato et al., 2004) were compared with those of the type strains of Cupriavidus species. The CLUSTAL W algorithm (Thompson et al., 1994) was used to align sequences and to construct a neighbourjoining tree with 1000 bootstrap iterations. For determination of DNA base composition, DNA was extracted, purified by phenol treatment (Saito \& Miura, 1963) and enzymically degraded into nucleosides. The nucleoside mixture was separated by reversed-phase HPLC as described by Tamaoka \& Komagata (1984). DNA-DNA hybridization experiments were carried out with photobiotin-labelled probes in microplate wells as described by Ezaki et al. (1989). For enzymic development, alkaline phosphatase-streptavidin conjugate (Vector) was used with CDP-Star (Tropix) as substrate and chemiluminescence was determined with a Wallac 1420 ARVOsx multilabel counter as described previously (Ushiba et al., 2003).

The ten bacteria isolated from the volcanic mudflow deposits were strictly aerobic, Gram-negative, non-sporulating, catalase-positive rods $(0 \cdot 3-0.6 \times 0 \cdot 8-1 \cdot 6 \mu \mathrm{m})$. Their phenotypic characteristics determined by the API 20NE kit test were very similar. All of them reduced nitrate to nitrite but not further to $\mathrm{N}_{2}$, possessed urease and oxidase activities and assimilated gluconate, caprate, adipate, malate, citrate and phenylacetate. None of the strains produced indole, acids from glucose, $\beta$-glucosidase, protease or $\beta$-galactosidase. None of the strains assimilated arabinose, mannose, mannitol, $\mathrm{N}$-acetyl-D-glucosamine or maltose. Strain 1247 utilized glucose, but the other strains did not. Six strains $\left(1243,1244 \mathrm{a}, 1245^{\mathrm{T}}, 1247,1250\right.$ and $\left.1278 \mathrm{a}\right)$ produced arginine dihydrolase.

When the almost-complete 16S rRNA gene sequences of the ten strains comprising 1523-1525 nt were compared to each other, nine strains $\left(1243,1244 \mathrm{a}, 1245^{\mathrm{T}}, 1246 \mathrm{a}, 1247,1249\right.$, 1250,1266 and 1278a) formed a homogeneous group with very high similarities (99.7-100\%): the group was named group P. The similarities of the group P strains to the other strain $\left(1263 \mathrm{a}^{\mathrm{T}}\right)$ were $98 \cdot 6-98 \cdot 7 \%$. Phylogenetic analysis of the sequences of the ten strains under study, five Ralstonia species, Ralstonia sp. LMG 1197 and nine Cupriavidus 
species confirmed that the ten strains belonged to the genus Cupriavidus and formed a separate phylogenetic cluster in the tree (Fig. 1). Within the cluster, strain $1263 \mathrm{a}^{\mathrm{T}}$ formed a distinct branch with group $\mathrm{P}$ (a bootstrap resampling value of $94 \%)$. The closest relatives of the group $\mathrm{P}$ strains and $1263 \mathrm{a}^{\mathrm{T}}$ among the type strains of established Cupriavidus species were $C$. basilensis, with sequence similarities of $98 \cdot 1-98 \cdot 3 \%$ and $97 \cdot 1 \%$, respectively, and C. taiwanensis, with sequence similarities of $98 \cdot 0-98 \cdot 2 \%$ and $97 \cdot 8 \%$, respectively. Ralstonia sp. LMG 1197 clustered together with the group P strains and was clearly separate from the clusters of Ralstonia species. The 16S rRNA gene sequence similarities between Ralstonia sp. LMG 1197 and strains of group $\mathrm{P}$ and $1263 \mathrm{a}^{\mathrm{T}}$ were $99 \cdot 5-99 \cdot 7 \%$ and $98.6 \%$, respectively. The homogeneity of group $\mathrm{P}$ was further confirmed by the same overall protein-banding pattern in whole-cell protein electrophoretic profiling (see Supplementary Fig. S1 in IJSEM Online). In the following taxonomic analyses, strain $1245^{\mathrm{T}}$ was used as the representative of group $\mathrm{P}$ and tested together with strain $1263 \mathrm{a}^{\mathrm{T}}$.

Because Ralstonia sp. LMG 1197 clustered with the group P strains on the phylogenetic tree, the genomic relatedness between strain $1245^{\mathrm{T}}$ and Ralstonia sp. LMG 1197 was determined by DNA-DNA hybridization. Strain $1245^{\mathrm{T}}$ exhibited a high level (91\%) of DNA-DNA relatedness to Ralstonia sp. LMG 1197, indicating that these strains are related each other at the species level. DNA-DNA hybridization values were also determined with the following pairs of strains: $1245^{\mathrm{T}} / 1263 \mathrm{a}^{\mathrm{T}}(44 \%) ; 1245^{\mathrm{T}} /$ C. basilensis DSM $11853^{\mathrm{T}}(46 \%) ; 1263 \mathrm{a}^{\mathrm{T}} /$ C. basilensis DSM $11853^{\mathrm{T}}$ (50\%); and $1263 \mathrm{a}^{\mathrm{T}} /$ Ralstonia sp. LMG 1197 (53\%). These values did not reveal relatedness at the species level for any of these pairs. Strains $1245^{\mathrm{T}}$ and $1263 \mathrm{a}^{\mathrm{T}}$ and the type strains of established Cupriavidus species were further compared by SDS-PAGE of whole-cell proteins, a method that has often been proven to differentiate at the species level (Pot et al., 1994; Kersters \& De Ley, 1975): indeed, in the genera Ralstonia and Cupriavidus, high protein electrophoretic similarity correlates with a high level of DNA-DNA hybridization (Coenye et al., 1999, 2003a; Vandamme et al., 1999; Goris et al., 2001; Vandamme \& Coenye, 2004). UPGMA cluster analysis of SDS-PAGE protein profiles showed that strain $1245^{\mathrm{T}}$ and Ralstonia sp. LMG 1197 formed a cluster at the similarity level of $87 \%$ and were distinct from strain $1263 \mathrm{a}^{\mathrm{T}}$ (67\% similarity) and the other type strains of Cupriavidus species (less than $78 \%$ similarity) (Fig. 2).

The predominant respiratory lipoquinone detected in strains $1245^{\mathrm{T}}$ and $1263 \mathrm{a}^{\mathrm{T}}$ was ubiquinone-8 (Q-8) and the DNA G $+C$ contents of the strains were 65.9 and $65 \cdot 2 \mathrm{~mol} \%$, respectively. Utilization of aromatic compounds was included in the phenotypic characterization because Ralstonia sp. LMG 1197, which is closely related to strain $1245^{\mathrm{T}}$, is known to be able to degrade several aromatic and chlorinated aromatic compounds (Clement

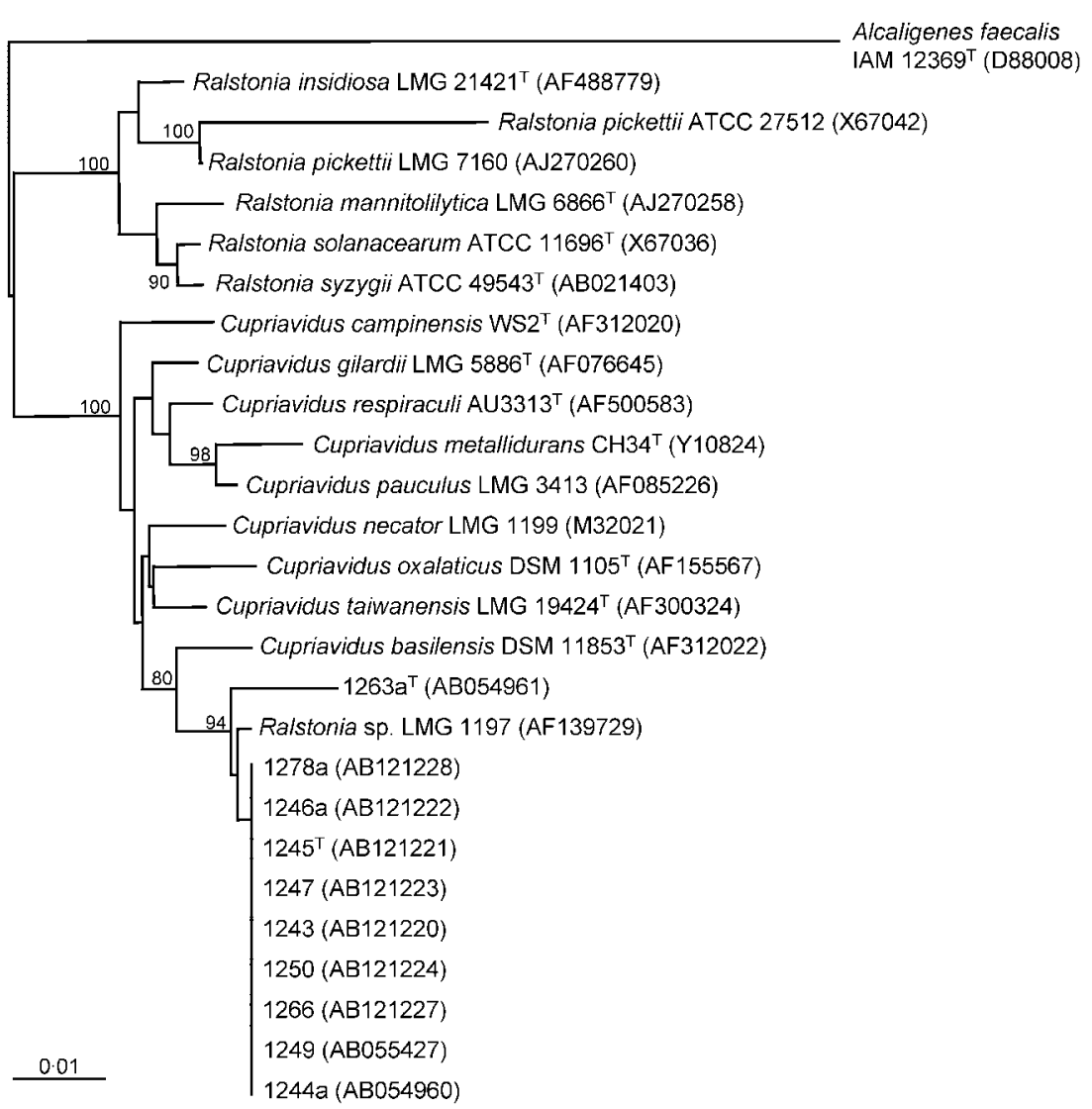

Fig. 1. Neighbour-joining tree (Saitou \& Nei, 1987) based on 16S rRNA gene sequences (continuous stretch, 1409-1420 nt) showing the positions of strains $1245^{\top}$ and $1263 \mathrm{a}^{\top}$ among their phylogenetic neighbours. Sequences of reference species were obtained from DDBJ and GenBank and the $16 \mathrm{~S}$ rRNA coding sequence of Alcaligenes faecalis IAM $12369^{\top}$ was selected as an outgroup. Sequences were aligned using CLUSTAL W (Thompson et al., 1994). The tree was visualized using TREEVIEW (Page, 1996). Numbers on branch nodes are bootstrap values (only those above $50 \%$ are shown) expressed as a percentage (1000 resamplings). Bar, 0.01 substitutions per nucleotide position. 


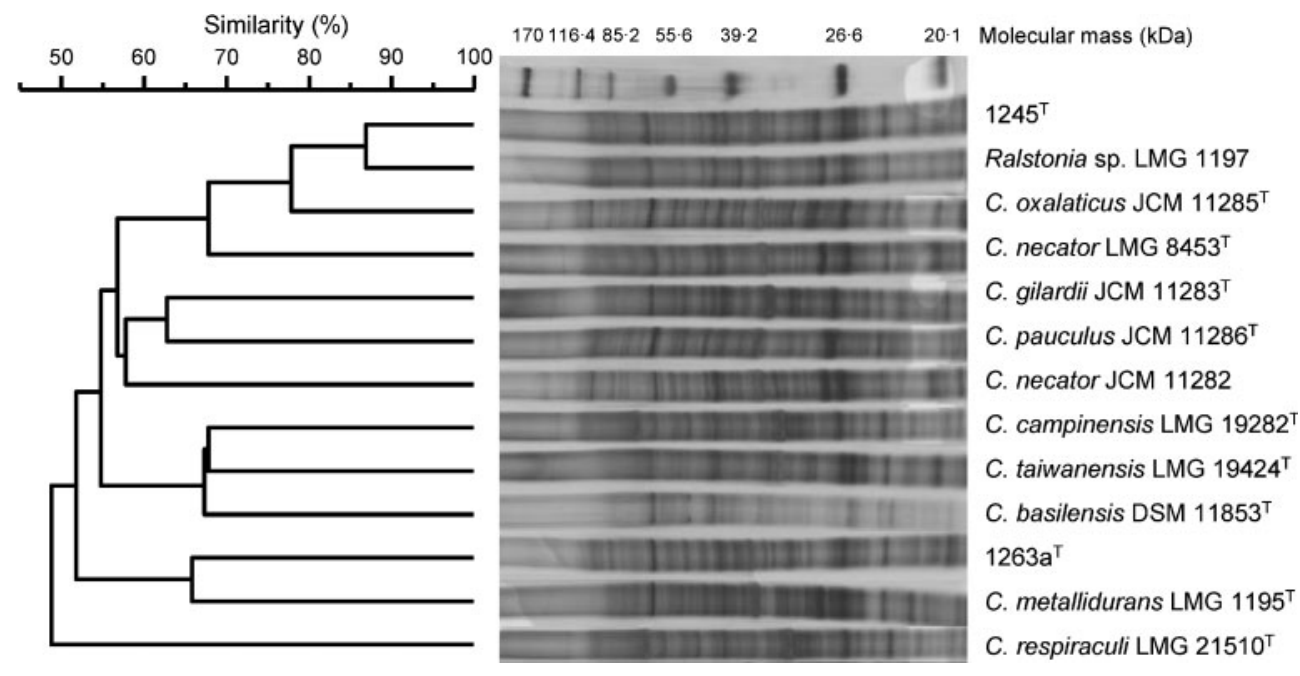

Fig. 2. Whole-cell protein profiles of strains $1245^{\top}$ and $1263 \mathrm{a}^{\top}$ and the type strains of established Cupriavidus species and the corresponding dendrogram derived from UPGMA cluster analysis of simple matching coefficient.

et al., 1995). Utilization of ten aromatic compounds and six organic acids by strain $1245^{\mathrm{T}}$, strain $1263 \mathrm{a}^{\mathrm{T}}$, Ralstonia sp. LMG 1197 and C. basilensis DSM $11853^{\mathrm{T}}$ was tested and substrate utilization profiles were compared. Seven out of ten aromatic compounds were used by strain $1245^{\mathrm{T}}$, Ralstonia sp. LMG 1197 and C. basilensis DSM $11853^{\mathrm{T}}$. The utilization profile of strain $1245^{\mathrm{T}}$ was the same as that of Ralstonia sp. LMG 1197: benzoate, caffeate, catechol, phenol, 2-hydroxybenzoate, 3,4-dihydroxybenzoate and 4-hydroxybenzoate were used, but ferulate, guaiacol and vanillate were not used. C. basilensis DSM $11853^{\mathrm{T}}$ also used a wide range of aromatic compounds: benzoate, caffeate, catechol, phenol, 2-hydroxybenzoate, 4-hydroxybenzoate and vanillate. In contrast, strain $1263 \mathrm{a}^{\mathrm{T}}$ utilized a narrower range of aromatic compounds (caffeate, catechol, phenol and vanillate). Other phenotypic characteristics of strains $1245^{\mathrm{T}}$ and $1263 \mathrm{a}^{\mathrm{T}}$ are shown in Table 1 or are given in the species description.

Table 1. Phenotypic characteristics of strain $1245^{\top}$, strain $1263 a^{\top}$, Ralstonia sp. LMG 1197, C. basilensis DSM $11853^{\top}$, C. necator JCM 11282 and other members of the genus Cupriavidus

Strains/species: 1 , strain $1245^{\mathrm{T}} ; 2$, Ralstonia sp. LMG 1197; 3, strain $1263 \mathrm{a}^{\mathrm{T}} ; 4$, C. oxalaticus; 5, C. basilensis DSM $11853^{\mathrm{T}}$; 6, C. necator JCM 11282; 7, C. taiwanensis; 8, C. campinensis; 9, C. metallidurans; 10, C. pauculus; 11, C. gilardii; 12, C. respiraculi. Data are consolidated from our experiments and Goris et al. (2001), Chen et al. (2001), Vandamme et al. (1999), Coenye et al. (1999, 2003b), Jenni et al. (1988) and Sahin et al. (2000). +, Positive; -, negative; d, variable result within the species; NA, no data available.

\begin{tabular}{|c|c|c|c|c|c|c|c|c|c|c|c|c|}
\hline Characteristic & 1 & 2 & 3 & 4 & 5 & 6 & 7 & 8 & 9 & 10 & 11 & 12 \\
\hline Nitrate to nitrite reduction & + & + & + & + & - & + & + & + & + & - & - & $\mathrm{d}$ \\
\hline Nitrate to $\mathrm{N}_{2}$ reduction & - & - & - & + & - & + & NA & - & $\mathrm{d}$ & - & - & NA \\
\hline Growth at $41{ }^{\circ} \mathrm{C}$ & - & - & + & - & - & + & - & + & - & + & + & + \\
\hline Arginine dihydrolase & + & + & + & + & - & + & - & - & - & - & + & - \\
\hline Urease & + & + & + & + & - & + & - & + & - & + & - & - \\
\hline \multicolumn{13}{|l|}{ Assimilation of: } \\
\hline N-Acetyl-D-glucosamine & - & - & - & - & - & + & - & - & - & - & - & - \\
\hline Adipate & + & + & + & + & + & + & - & + & + & + & $\mathrm{d}$ & + \\
\hline Citrate & + & + & + & + & + & + & $\mathrm{d}$ & - & + & + & $\mathrm{d}$ & - \\
\hline Phenylacetate & + & + & + & + & + & + & + & + & + & + & $\mathrm{d}$ & - \\
\hline Acetate & + & + & - & - & - & + & - & - & - & - & - & - \\
\hline Lactate & + & + & - & + & - & + & + & + & + & + & + & + \\
\hline Glutamate & + & + & - & + & - & + & + & + & + & + & + & + \\
\hline Vanillate & - & - & + & - & + & - & - & - & - & - & - & - \\
\hline 3,4-Dihydroxybenzoate & + & + & - & - & - & + & - & - & - & + & - & - \\
\hline
\end{tabular}


On the basis of the data presented, two novel species within the genus Cupriavidus are proposed, with the names Cupriavidus pinatubonensis sp. nov. (type strain $1245^{\mathrm{T}}$ ) and Cupriavidus laharis sp. nov. (type strain $1263 \mathrm{a}^{\mathrm{T}}$ ). In addition, our results indicate that Ralstonia sp. LMG 1197 should be placed in the novel species $C$. pinatubonensis. The phenotypic characteristics that differentiate the two novel species from other Cupriavidus species are summarized in Table 1.

\section{Description of Cupriavidus pinatubonensis sp. nov.}

Cupriavidus pinatubonensis (pin.a.tu.bo.nen'sis. N.L. masc. adj. pinatubonensis pertaining to Mt. Pinatubo, the volcano on Luzon Island, the Philippines, from which first strains were isolated).

Cells are aerobic, Gram-negative, non-sporulating, peritrichously flagellated rods $(0 \cdot 3-0 \cdot 6 \times 0 \cdot 8-1 \cdot 6 \mu \mathrm{m})$. Colonies on 100-fold diluted NB agar are circular, entire, convex, opaque and white. Growth is observed in NB and 10-fold and 100 -fold diluted $\mathrm{NB}$ at 27,30 and $41{ }^{\circ} \mathrm{C}$. Oxidase, catalase and urease are present; protease, $\beta$-galactosidase and $\beta$-glucosidase are not present. No indole production or production of acid from glucose occurs. Nitrate is reduced to nitrite, but not further to $\mathrm{N}_{2}$. Assimilates gluconate, caprate, adipate, malate, citrate, phenylacetate, D-fructose, acetate, glutamate, lactate, benzoate, caffeate, catechol, phenol, 2-hydroxybenzoate, 3,4-dihydroxybenzoate and 4-hydroxybenzoate, but not glucose, arabinose, mannose, mannitol, $\mathrm{N}$-acetyl-D-glucosamine, maltose, sucrose, formate, ferulate, guaiacol or vanillate. Chemolithoautotrophic growth occurs in the presence of hydrogen, oxygen and carbon dioxide. The major isoprenoid quinone is ubiquinone Q-8.

The type strain is $1245^{\mathrm{T}}\left(=\right.$ CIP $\left.108725^{\mathrm{T}}=\mathrm{PNCM} 10346^{\mathrm{T}}\right)$, isolated from volcanic mudflow deposits sampled around Mt. Pinatubo, the Philippines. The DNA G + C content of strain $1245^{\mathrm{T}}$ is $65.9 \mathrm{~mol} \%$.

\section{Description of Cupriavidus laharis sp. nov.}

Cupriavidus laharis (la.har' is. N.L. gen. n. laharis of a lahar, a volcanic mudflow).

Cells are Gram-negative, aerobic, non-sporulating, peritrichously flagellated rods $(0.3-0.6 \times 0.8-1.6 \mu \mathrm{m})$. Colonies on 100-fold diluted NB agar are circular, entire, convex, opaque and white. Growth is observed in NB and 10-fold and 100 -fold diluted NB at 27 and $30^{\circ} \mathrm{C}$, but not at $41^{\circ} \mathrm{C}$. Oxidase, catalase and urease are present; protease, $\beta$ galactosidase and $\beta$-glucosidase are not present. No indole production or production of acid from glucose occurs. Nitrate is reduced to nitrite, but not further to $\mathrm{N}_{2}$. Assimilates gluconate, caprate, adipate, malate, citrate, phenylacetate, D-fructose, acetate, caffeate, catechol, phenol and vanillate, but not sucrose, formate, glutamate, lactate, benzoate, ferulate, guaiacol, 2-hydroxybenzoate, 3,4-dihydroxybenzoate or 4-hydroxybenzoate. Chemolithoautotrophic growth occurs in the presence of hydrogen, oxygen and carbon dioxide. The major isoprenoid quinone is ubiquinone $\mathrm{Q}-8$.

The type strain is $1263 \mathrm{a}^{\mathrm{T}}\left(=\mathrm{CIP} 108726^{\mathrm{T}}=\operatorname{PNCM} 10347^{\mathrm{T}}\right)$, isolated from volcanic mudflow deposits sampled around Mt. Pinatubo, the Philippines. The DNA G $+\mathrm{C}$ content of strain $1263 \mathrm{a}^{\mathrm{T}}$ is $65 \cdot 2 \mathrm{~mol} \%$.

\section{Acknowledgements}

We thank Professor T. Ohmachi, Leader of JSPS Project 'Impact analysis of metropolitan policies for development and environmental conservation in the Philippines', for his understanding and encouragement through our research activities. We also thank Dr M. Araragi, Leader of the JICA team, and all of our Philippine and Japanese colleagues in the Bureau of Soils and Water Management, Philippines, for their cooperation and support during our field survey in Pampanga. We also wish to thank Dr Y. Suwa for advice concerning UPGMA clustering.

\section{References}

Chadwick, O. A., Derry, L. A., Vitousek, P. M., Huebert, B. J. \& Hedin, L. O. (1999). Changing sources of nutrients during four million years of ecosystem development. Nature 397, 491-497.

Chen, W. M., Laevens, S., Lee, T. M., Coenye, T., De Vos, P., Mergeay, M. \& Vandamme, P. (2001). Ralstonia taiwanensis sp. nov., isolated from root nodules of Mimosa species and sputum of a cystic fibrosis patient. Int J Syst Evol Microbiol 51, 1729-1735.

Clement, P., Matus, V., Cardenas, L. \& Gonzalez, B. (1995). Degradation of trichlorophenols by Alcaligenes eutrophus JMP134. FEMS Microbiol Lett 127, 51-55.

Coenye, T., Falsen, E., Vancanneyt, M., Hoste, B., Govan, J. R. W., Kersters, K. \& Vandamme, P. (1999). Classification of Alcaligenes faecalis-like isolates from the environment and human clinical samples as Ralstonia gilardii sp. nov. Int J Syst Bacteriol 49, 405-413.

Coenye, T., Goris, J., De Vos, P., Vandamme, P. \& LiPuma, J. J. (2003a). Classification of Ralstonia pickettii-like isolates from the environment and clinical samples as Ralstonia insidiosa sp. nov. Int J Syst Evol Microbiol 53, 1075-1080.

Coenye, T., Vandamme, P. \& LiPuma, J. J. (2003b). Ralstonia respiraculi sp. nov., isolated from the respiratory tract of cystic fibrosis patients. Int J Syst Evol Microbiol 53, 1339-1342.

Conrad, R. (1996). Soil microorganisms as controllers of atmospheric trace gases $\left(\mathrm{H}_{2}, \mathrm{CO}, \mathrm{CH}_{4}\right.$, OCS, $\mathrm{N}_{2} \mathrm{O}$, and $\left.\mathrm{NO}\right)$. Microbiol Rev 60, 609-640.

Crews, T. E., Kurina, L. M. \& Vitousek, P. M. (2001). Organic matter and nitrogen accumulation and nitrogen fixation during early ecosystem development in Hawaii. Biogeochemistry 52, 259-279.

Ezaki, T., Hashimoto, Y. \& Yabuuchi, E. (1989). Fluorometric deoxyribonucleic acid-deoxyribonucleic acid hybridization in microdilution wells as an alternative to membrane filter hybridization in which radioisotopes are used to determine genetic relatedness among bacterial strains. Int J Syst Bacteriol 39, 224-229.

Goris, J., De Vos, P., Coenye, T. \& 7 other authors (2001). Classification of metal-resistant bacteria from industrial biotopes as Ralstonia campinensis sp. nov., Ralstonia metallidurans sp. nov. and Ralstonia basilensis Steinle et al. 1998 emend. Int J Syst Evol Microbiol 51, 1773-1782. 
Jackson, T. A. \& Keller, W. D. (1970). Comparative study of the role of lichens and inorganic processes in the chemical weathering of recent Hawaiian lava flows. Am J Sci 269, 446-466.

Jenni, B., Realini, L., Aragno, M. \& Tamer, A. U. (1988). Taxonomy of non $\mathrm{H}_{2}$-lithotrophic, oxalate-oxidizing bacteria related to Alcaligenes eutrophus. Syst Appl Microbiol 10, 126-133.

Kersters, K. \& De Ley, J. (1975). Identification and grouping of bacteria by numerical analysis of their electrophoretic protein patterns. J Gen Microbiol 87, 333-342.

King, G. M. (2003). Contributions of atmospheric CO and hydrogen uptake to microbial dynamics on recent Hawaiian volcanic deposits. Appl Environ Microbiol 69, 4067-4075.

Kurina, L. M. \& Vitousek, P. M. (1999). Controls over the accumulation and decline of a nitrogen-fixing lichen, Stereocaulon vulcani, on young Hawaiian lava flows. J Ecol 87, 784-799.

Laemmli, U. K. (1970). Cleavage of structural proteins during the assembly of the head of bacteriophage T4. Nature 227, 680-685.

Ohta, H. \& Hattori, T. (1983). Agromonas oligotrophica gen. nov., sp. nov., a nitrogen-fixing oligotrophic bacterium. Antonie van Leeuwenhoek 49, 429-446.

Ohta, H., Hara, H., Fukui, K., Kurihara, H., Murayama, Y. \& Kato, K. (1993). Association of Actinobacillus actinomycetemcomitans leukotoxin with nucleic acids on the bacterial cell surface. Infect Immun 61, 4878-4884.

Ohta, H., Ogiwara, K., Murakami, E. \& 9 other authors (2003). Quinone profiling of bacterial populations developed in the surface layer of volcanic mudflow deposits from Mt. Pinatubo (the Philippines). Soil Biol Biochem 35, 1155-1158.

Page, R. D. M. (1996). TREEVIEW: an application to display phylogenetic trees on personal computers. Comput Appl Biosci 12, 357-358.

Pemberton, J., Corney, B. \& Don, R. H. (1979). Evolution and spread of pesticide degrading ability among soil micro-organisms. In Plasmids of Medical, Environmental and Commercial Importance, pp. 287-299. Edited by K. Timmis \& A. Puhler. Amsterdam: Elsevier/North-Holland Biomedical.

Pot, B., Devriese, L. A., Hommez, J., Miry, C., Vandemeulebroecke, K., Kersters, K. \& Haesebrouck, F. (1994). Characterization and identification of Vagococcus fluvialis strains isolated from domestic animals. J Appl Bacteriol 77, 362-369.

Sahin, N., Isik, K., Tamer, A. Ü. \& Goodfellow, M. (2000). Taxonomic position of "Pseudomonas oxalaticus" strain Ox1 ${ }^{\mathrm{T}}\left(\mathrm{DSM} 1105^{\mathrm{T}}\right)$ (Khambata and Bhat, 1953) and its description in the genus Ralstonia as Ralstonia oxalatica comb. nov. Syst Appl Microbiol 23, 206-209.

Saito, H. \& Miura, K. (1963). Preparation of transforming deoxyribonucleic acid by phenol treatment. Biochim Biophys Acta 72, 619-629.

Saitou, N. \& Nei, M. (1987). The neighbor-joining method: a new method for reconstructing phylogenetic trees. Mol Biol Evol 4, 406-425.

Sato, Y., Nishihara, H., Yoshida, M., Watanabe, M., Rondal, J. D. \& Ohta, H. (2004). Occurrence of hydrogen-oxidizing Ralstonia species as primary microorganisms in the Mt. Pinatubo volcanic mudflow deposit. Soil Sci Plant Nutr 50, 855-861.

Tamaoka, J. \& Komagata, K. (1984). Determination of DNA base composition by reversed-phase high-performance liquid chromatography. FEMS Microbiol Lett 25, 125-128.

Thompson, J. D., Higgins, D. G. \& Gibson, T. J. (1994). ClUSTAL W: improving the sensitivity of progressive multiple sequence alignment through sequence weighting, position-specific gap penalties and weight matrix choice. Nucleic Acids Res 22, 4673-4680.

Ushiba, Y., Takahara, Y. \& Ohta, H. (2003). Sphingobium amiense sp. nov., a novel nonylphenol-degrading bacterium isolated from a river sediment. Int J Syst Evol Microbiol 53, 2045-2048.

Vandamme, P. \& Coenye, T. (2004). Taxonomy of the genus Cupriavidus: a tale of lost and found. Int J Syst Evol Microbiol 54, 2285-2289.

Vandamme, P., Goris, J., Coenye, T., Hoste, B., Janssens, D., Kersters, K., De Vos, P. \& Falsen, E. (1999). Assignment of Centers for Disease Control group IVc-2 to the genus Ralstonia as Ralstonia paucula sp. nov. Int J Syst Bacteriol 49, 663-669.

Vaneechoutte, M., Kampfer, P., De Baere, T., Falsen, E. \& Verschraegen, G. (2004). Wautersia gen. nov., a novel genus accommodating the phylogenetic lineage including Ralstonia eutropha and related species, and proposal of Ralstonia [Pseudomonas] syzygii (Roberts et al. 1990) comb. nov. Int J Syst Evol Microbiol 54, 317-327. 